\title{
PENGARUH FAKTOR FUNDAMENTAL TERHADAP HARGA SAHAM SYARIAH PADA PERUSAHAAN YANG TERDAFTAR DI JAKARTA ISLAMIC INDEK PERIODE 2011 - 2016
}

\author{
Desi Sulfa Ningtias \\ Departemen Ekonomi Syariah - Fakultas Ekonomi dan Bisnis - Universitas Airlangga \\ Email: desi.sulfa-13@feb.unair.ac.id \\ Nisful Laila \\ Departemen Ekonomi Syariah - Fakultas Ekonomi dan Bisnis - Universitas Airlangga \\ Email: nisful.laila@feb.unair.ac.id
}

\begin{abstract}
:
This research aims to determine the effect of ROA, EPS and DER of sharia stock price in the Jakarta Islamic Index partially or simultaneously. This research uses a quantitative approach with multiple linear regression analysis using panel data. The population used in this study is companies registered in the Jakarta Islamic Index, while the sample research is ten companies in the Jakarta Islamic Index that meet the criteria of purposive sampling. The period of this research is for six years from 2011 - 2016. The result showed that ROA, EPS and $D E R$ simultaneously and significantly influence sharia stock price. And partially $R O A$ variable has no significant influence on sharia stock price. And partially independent ROA variable does not significantly influence stock price while EPS and DER have significant influence on sharia stock price for companies registered in the Jakarta Islamic Index period 2011-2016.
\end{abstract}

Keywords: Sharia stock price, Return On Assets, Earning Per Share, and Debt to Equity Ratio,

\section{PENDAHULUAN}

Saat ini, perkembangan ekonomi syariah sangat pesat beberapa tahun belakangan. Hal tersebut ditandai dengan banyaknya perkembangan industri keuangan yang berbasis syariah, diantaranya adalah investasi. Investasi merupakan salah satu bagian terpenting dalam kegiatan ekonomi syariah. Kegiatan investasi sangat dianjurkan oleh islam karena hal tersebut merupakan salah satu kegiatan muamalah yang dapat meningkatkan nilai guna dari harta yang kita miliki. Investasi memberikan manfaat kepada seseorang unuk mengembangkan hartanya agar lebih bermanfaat bagi orang lain. Salah satu dalil Qur'an yang menganjurankan umat muslim untuk berinvestasi yaitu terdapat dalam Surat AlLuaman 31 Ayat 34:

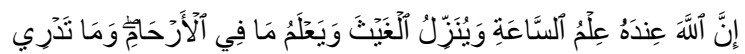

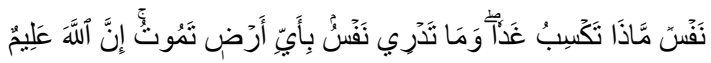

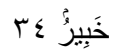

'Inna-allaha 'indahë 'ilmu-ssÉ'ati wayunazzilu algaytsa waya'lamu $m E ́$ fế al'arí́mi wa $m E ́$ tadrÊnafsun-mÉĐÉ taksibu gadÉ wamÉ tadrÊnafsunbi 'ayyi 'arìntamËtu 'inna allaha 'alÊmun khabÊrun. Artinya: "Sesungguhnya Allah, hanya pada sisi-Nya sajalah pengetahuan tentang Hari Kiamat; dan Dialah Yang menurunkan hujan, dan mengetahui apa yang ada dalam rahim. Dan tiada seorangpun yang dapat mengetahui (dengan pasti) apa yang akan diusahakannya besok. Dan tiada seorangpun yang dapat mengetahui di bumi mana dia akan mati. Sesungguhnya Allah Maha Mengetahui lagi Maha Mengenal." (Al Luqman : 34).

Tandelilin (2010:1) mengemukakan bahwa "investasi dapat diartikan sebagai

1) Jurnal ini merupakan bagian dari Skripsi Desi Sulfa Ningtias, NIM: 041311433020 yang diuji pada tanggal 23 Juli 2018. 
Ningtias, et al/Jurnal Ekonomi Syariah Teori dan Terapan Vol. 6 No. 1 Januari 2019: 70-81; PENGARUH FAKTOR FUNDAMENTAL TERHADAP HARGA SAHAM SYARIAH PADA PERUSAHAAN YANG TERDAFTAR DI JAKARTA ISLAMIC INDEK PERIODE 2011-2016

komitmen untuk menanamkan sejumlah dana pada saat ini dengan tujuan memperoleh keuntungan di masa mendatang". Investasi dapat dilakukan pada dua kegiatan, yaitu kegiatan dalam sektor riil dan sektor keuangan. Contoh dari sektor riil adalah investasi pada properti dan lain - lain dalam bentuk nyata. Sedangkan investasi pada sektor keuangan berupa investasi saham, sukuk, reksadana dan sebagainya yang dilakukan di pasar vang ataupun pasar modal.

Dari beberapa instrumen keuangan, saham menjadi instrumen yang paling diminati oleh investor karena saham mampu memberikan tingkat keuntungan yang besar. Saham sendiri merupakan sertifikat kepemilikan atas perusahaan. Oleh karena dalam pasar modal dibentuk index khusus tentang saham.

Jakarta islamic Index merupakan index yang berkaitan dengan saham syariah. PT. Bursa Efek Indonesia (BEI) bersama dengan PT. Danareksa Investment Management (DIM) meluncurkan Jakarta Islamic Index pada tanggal 3 Juli 2000 dengan tujuan untuk mempermudah investor muslim dan memandu investor yang ingin menginvestasikan dananya secara syariah. Selain itu, Jakarta Islamic Index menjadi tolak ukur dalam menilai kinerja investasi terhadap saham dengan prinsip syariah.

Sebelum melakukan investasi, investor terlebih dahulu perlu mengetahui dan mempertimbangkan kinerja dari perusahaan. Maka diperlukan Informasi yang akurat untuk mengetahui faktor - faktor yang mempengaruhi pergerakan harga. Maka dibutuhkan analisis untuk mengukur pengaruh tersebut yaitu dengan analisis fundamental (internal perusahaan) dan analisis teknikal (eksternal perusahaan)

Tandelilin (2010:243) mengemukakan bahwa "Analisis fundamental merupakan analisis saham yang dilakukan dengan mengestimasi nilai intrinsik saham bedasarkan informasi fundamental yang telah dipublikasikan perusahaan seperti laporan keuangan, perubahan dividen dan lainnya". Sedangkan menurut J. Fred Weston bentuk - bentuk rasio keuangan dibagi menjadi 6 rasio yaitu rasio likuiditas, rasio solvabilitas, rasio aktivity, rasio profitabilitas, rasio pertumbuhan, dan rasio penilaian (Kasmir, 2015:106).

Penelitian ini menggunakan variabel variabel fundamental yaitu return on asset, earning per share, dan debt to equity ratio

Rumusan masalah dalam penelitian ini adalah apakah terdapat pengaruh antara return on asset, earning per share, dan debt to equity ratio terhadap harga saham di Jakarta Islamic Index periode 201 1-2016.

Tujuan dari penelitian ini adalah untuk mengetahui pengaruh return on asset, earning per share, debt to equity ratio terhadap harga saham syariah di Jakarta Islamic Index periode 201 1-2016.

\section{LANDASAN TEORI}

Investasi secara umum dalam kegiatannya memiliki tiga aspek, yaitu aspek vang, waktu, dan manfaat. Haming dan Basalamah (2010:5) mengemukakan bahwa investasi merupakan suatu keputusan dalam mengeluarkan dana pada saat ini yang 
Ningtias, et al/Jurnal Ekonomi Syariah Teori dan Terapan Vol. 6 No. 1 Januari 2019: 70-81; PENGARUH FAKTOR FUNDAMENTAL TERHADAP HARGA SAHAM SYARIAH PADA PERUSAHAAN YANG TERDAFTAR DI JAKARTA ISLAMIC INDEK PERIODE 2011-2016

digunakan untuk membeli aktiva riil maupun aktiva keuangan, dengan tujuan untuk mendapatkan keuntungan dimasa yang akan datang.

Investasi merupakan salah satu kegiatan muamalat. Investasi dalam islam bukan hanya dipengaruhi faktor keuntungan materi saja, tapi juga sangat dipengarhi oleh faktor syariah (kepatuhan kepada ketentuan syariah) dan faktor sosial (kemaslahatan umat) (Yuliana 2010:15). Aktivitas investasi bukan hanya bertujuan untuk mendapatan keuntungan secara materi, namun kegiatan investasi dilandasi dengan motivasi ingin membantu beberapa pihak untuk kelangsungan usaha. Hal tersebut berkaitan dengan Al-Qur'an surat Al-Baqarah:261

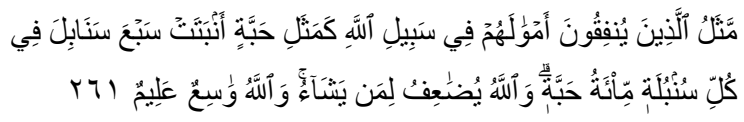
MatsalullaĐÊna yunfiqËna 'amwÉÉlahum fê sabÊli allahi kamatsali Íabbatin 'anbatat sanÉ bila fêE kulli sumbulati-mi 'atu Íabbatin wa allahu yuİE'ifu limanyasyÉ'u wa allahu wa si'un 'alÊmun

Artinya: "Perumpamaan orang yang menginfakkan hartanya di jalan Allah seperti sebutir biji yang menumbuhkan tujuh tangkai, pada setiap tangkai ada seratus biji. Allah melipat gandakan (ganjaran) bagi siapa yang Dia kehendaki, dan Allah Maha luas (karunia-Nya), Maha Mengetahui." (al Baqorah:261).

Menurut Undang-undang Pasar Modal no. 8 tahun 1995 menjelaskan bahwa: "Pasar Modal yaitu sebagai suatu kegiatan yang bersangkutan dengan penawaran umum dan perdagangan efek, perusahaan publik yang berkaitan dengan efek yang diterbitkannya, serta lembaga dan profesi yang berkaitan dengan efek." (Huda, 2010:220). Dalam perkembangannya dibentuk pasar modal syariah. Pasar modal syariah merupakan jenis pasar modal yang segala bentunya baik berupa akad, produk serta kegiatannya dijalankan dengan prinsip - prinsip syariah. instrumen keuangan yang terdapat di pasar modal syariah salah satunya yaitu saham syariah, sukuk dan reksadana syariah.

Bursa Efek Indonesia (BEl) bekerja sama dengan PT. Danareksa Invesment Management mendirikan Jakarta Islamc Index pada tanggal 3 Juli 2000 untuk memfasilitasi masyarakat dalam hal ini investor dan perusahaan publik untuk menjalankan kegiatan investasi yang sesuai dengan prinsip - prinsip syariah. Pada Jakarta Islamic Index ini terdiri dari 30 saham syariah yang memenuhi kriteria prinsip prinsip syariah yang telah ditetapkan oleh Dewan Syariah Nasional (DSN).

Samsul (2006:45) Saham adalah tanda bukti memiliki perusahaan dimana pemiliknya juga sebagai pemegang saham. Bukti bahwa seseorang merupakan pemegang saham perusahaan yaitu apabila mereka sudah tercatat sebagai pemegang saham dalam buku Daftar Pemegang Saham (DPS). Saham syariah yaitu bukti bukti yang diperoleh investor sebagai tanda penyertaaan modal pada perusahaan dengan landasan prinsip prinsip syariah.

Harga saham adalah titik temu (harga yang telah disepakati bersama) antara penawaran dan permintaan saham pada 
Ningtias, et al/Jurnal Ekonomi Syariah Teori dan Terapan Vol. 6 No. 1 Januari 2019: 70-81; PENGARUH FAKTOR FUNDAMENTAL TERHADAP HARGA SAHAM SYARIAH PADA PERUSAHAAN YANG TERDAFTAR DI JAKARTA ISLAMIC INDEK PERIODE 2011-2016

saat perdagangan saham. Harga saham merupakan harga konsensus diantara para investor (Samsul, 2006:269).

Investor yang ingin berinvestasi pada saham syariah, perlu menganalisis mengenai harga saham. Sebab Harga saham akan mengalami fluktuasi seiring dengan perubahan jumlah permintaan dan penawaran terhadap saham tersebut di pasar modal. Tingkat harga saham di pasar, menunjukkan kinerja dari perusahaan. oleh karenanya dibutuhkan analisis terkait harga saham.

Analisis fundamental merupakan salah satu analisis yang dilakukan pada inernal perusahaan. Analisis fundamental adalah analisis penentu harga saham yang didasarkan pada kesehatan keuangan sebuah emiten. Kesehatan keuangan ini dapat dilihat dan diukur berdasarkan analisis laporan kevangan yang berkaitan dengan rasio - rasio keuangan perusahaan. Menurut Tandelilin (2001:329), analisis fundamental merupakan suatu pendekatan yang digunakan untuk menganalisis suatu saham dengan berdasarkan pada data data perusahaan seperti earning, dividen, penjualan dan lainnya.

Berdasarkan uraian diatas hipotesis dalam penelitian ini adalah sebagai berikut: a. Faktor - faktor rasio keuangan perusahaan yang terdiri dari Return On Asset (ROA), , Earning per Share (EPS), dan Debt to Equity Ratio (DER) secara individu (parsial) mempunyai pengaruh terhadap harga saham syariah yang terdaftar di Jakarta Islamic Index tahun 2011 - 2016. b. Faktor - faktor rasio keuangan perusahaan yang terdiri dari Return On Asset (ROA), , Earning per Share (EPS), dan Debt to Equity Ratio (DER) secara bersama - sama (simultan) mempunyai pengaruh terhadap harga saham syariah yang terdaftar di Jakarta Islamic Index tahun 2011 - 2016.

\section{METODE PENELITIAN}

\section{Pendekatan Penelitian}

Pendekatan yang digunakan dalam penelitian ini adalah metode kuantitatif. Penelitian kuantitatif menitikberatkan pada perhitungan statistik, pengujian hipotesis, dan penggunaan data - data dari variabel - variabel yang dapat diukur sehingga pada penelitian ini akan diperoleh kesimpulan yang dapat digeneraisasikan (Ansori dan Iswati, 2009: 14).

\section{Definisi Operasional}

Definisi operasional dalam penelitian ini adalah sebagai berikut:

\section{Harga Saham}

Harga saham merupakan nilai dari saham sebagai akibat dari suatu transaksi perdagangan saham di pasar modal. Harga yang digunakan dalam penelitian ini adalah harga saham tahunan yang diambil dari closing price setiap akhir tahun pada masa periode penelitian.

\section{Return On Asset (ROA)}

Return on asset merupakan rasio yang menunjukkan sejauh mana kemampuan perusahaan dalam mengelolah aset asetnya untuk bisa menghasilkan laba. Rumusnya yaitu:

$$
R O A=\frac{\text { Laba Bersih Sebelum Pajak }}{\text { Jumlah Aset }}
$$


Ningtias, et al/Jurnal Ekonomi Syariah Teori dan Terapan Vol. 6 No. 1 Januari 2019: 70-81; PENGARUH FAKTOR FUNDAMENTAL TERHADAP HARGA SAHAM SYARIAH PADA PERUSAHAAN YANG TERDAFTAR DI JAKARTA ISLAMIC INDEK PERIODE 2011-2016

3. Earning Per Share

Tandelilin (2010:366) menyimpulkan bahwa earning per share adalah laba bersih yang siap dibagikan kepada pemegang saham dibagi dengan lembar saham perusahaan. Perhitungannya EPS dapat dirumuskan sebagai berikut:

$$
E P S=\frac{\text { Laba Setelah Pajak }}{\text { Jumlah Lembar Saham Yang Beredar }}
$$

4. Debt to Equity Ratio (DER)

Debt to equity ratio adalah rasio yang digunakan untuk menilai utang dengan equitas. DER dapat digunakan untuk melihat struktur modal perusahaan dan dapat mengukur kemampuan perusahaan dalam memenuhi kewajibannya untuk membayar hutang. Rumusnya adalah:

$$
D E R=\frac{\text { Total debt }}{\text { Total equity }}
$$

\section{Jenis dan Sumber Data}

Jenis data yang digunakan dalam penelitian ini adalah data sekunder dan termasuk data time series dan data cross section. Data pada penelitian ini diperoleh dari laporan keuangan perusahaan yang diterbitkan di idx.co.id pada periode 20112016.

\section{Populasi dan Sampel}

Populasi penelitian ini meliputi perusahaan yang terdaftar di Jakarta Islamic Index periode 2011-2016. Pengambilan sampel menggunakan teknik purposive sampling. Kriteria perushaan yang dijadikan sampel yaitu:

1. Perusahaan yang akan diteliti merupakan perusahaan yang terdaftar di JII pada awal periode penelitian sampai akhir periode penelitian yaitu pada tahun 2011 2016.

2. Perusahaan yang akan diteliti harus konsisten selama masa periode penelitian terdaftar di Jll yaitu pada tahn 2011 - 2016.

3. Perusahaan yang terdaftar di Jll tersebut harus menerbitkan laporran keuangan setiap akhir tahun. Laporan keuangan tersebut harus memuat informasi - informasi yang terkait dengan variabel yang akan digunakan dalam penelitian ini.

Tabel 1.

Daftar perusahaan sebagai sampel penelitian

\begin{tabular}{|c|c|}
\hline No & Nama Perusahaan \\
\hline 1. & Astra Agro Lestari Tbk. \\
\hline 2. & Astra International Tbk. \\
\hline 3. & Indocement Tunggal Prakarsa Tbk. \\
\hline 4. & Kalbe Farma Tbk. \\
\hline 5. & Lipo Karawaci Tbk. \\
\hline 6. & Semen Indonesia (Persero)Tbk. \\
\hline 7. & United Tractors Tbk. \\
\hline 8. & Telekomunikasi Indonesia (Persero) Tbk. \\
\hline 9. & Unilever Indonesia Tbk. \\
\hline 10. & PP \\
\hline
\end{tabular}

Sumber: www.idx.co.id (data diolah)

\section{Teknik Analisis}

Penelitian ini menggunakan teknik analisis model multiple regretion dengan menggunakan data panel. Data panel merupakan metode penelitian yang menggabungkan dua data yaitu data time series (selama beberapa tahun tertentu) dan cross section (pada beberapa perusahaan tertentu). Data panel memiliki kelebihan tersendiri dibanding dengan data cross section ataupun time series. 
Ningtias, et al/Jurnal Ekonomi Syariah Teori dan Terapan Vol. 6 No. 1 Januari 2019: 70-81; PENGARUH FAKTOR FUNDAMENTAL TERHADAP HARGA SAHAM SYARIAH PADA PERUSAHAAN YANG TERDAFTAR DI JAKARTA ISLAMIC INDEK PERIODE 2011-2016

\section{Metode Analisis Data Panel}

Metode ini memiliki 3 jenis pendekatan yang digunakan dalam menentukan model estimasi, diantaranya yaitu:

1. Pooled Least Square (PLS) atau Common Effect (CEM). Analisis ini mengabungkan data time series dan data cross section tanpa melihat perbedaan antara waktu dan individu sehingga perilaku data antar perusahaan diasumsikan sama dalam berbagai kurun waktu.

2. Fixed effect Model (FEM). Teknik yang mengestimasi data panel dengan berasumsi terdapat perbedaan antara perilaku individu atau cross section berbeda dalam kurun waktu yang sama. Untuk dapat menangkap adanya perbedaan tersebut digunakan variabel dummy.

3. Random Effect Model (REM). Model ini digunakan untuk mengestimasi data panel dimana variabel gangguan mungkin saling berhubungan antar waktu dan antar individu.

\section{Hasil dan Pembahasan}

\section{Pemilihan Model Estimasi Data Panel}

\section{Uji Chow}

Tabel 2.

Hasil Uji Chow

\begin{tabular}{lcrr}
$\begin{array}{l}\text { Redundant Fixed Effects Tests } \\
\text { Equation: Untitled } \\
\text { Test cross-sectionfixed effects }\end{array}$ & & & \\
\hline \hline Effects Test & Statistic & d.f. & Prob. \\
\hline \hline Cross-sectionF & 7.060085 & $(9,47)$ & 0.0000 \\
Cross-section Chi-square & 51.314208 & 9 & 0.0000 \\
\hline \hline
\end{tabular}

Berdasarkan hasil perhitungan tersebut, diketahui hasil uji chow pada penelitian ini menunjukkan nilai Chi Square $(0,0000)<a$ $(0,05)$. Hasil pengujian ini yang menunjukkan Fixed Effect Model (FEM) . selanjutnya dilakukan uji Hausman. Untuk memilih model estimasi terbaik antara Fixed Effect Model (FEM) dan Random Effect Model (REM).

\section{Uji Hausman}

Tabel 3.

Hasil Uji Hausman

Correlated Random Effects - Hausman Test

Equation: Untitled

Test cross-section random effects

\begin{tabular}{lrrr}
\hline \hline TestSummary & $\begin{array}{c}\text { Chi-Sq. } \\
\text { Statistic }\end{array}$ & Chi-Sq. d.f. & Prob. \\
\hline \hline Cross-sectionrandom & 29.552374 & 3 & 0.0000 \\
\hline
\end{tabular}

Hasil tersebut menunjukkan probabilitas Chi-Square Statistics $=0,0000<a(0,05)$. Hasil tersebut menjelaskan bahwa $\mathrm{H}_{0}$ ditolak dan $\mathrm{H}_{1}$ diterima, yang artinya model estimasi yang dipilih pada pengujian Hausman ini adalah Fixed Effect Model (FEM).

Berdasarkan hasil dari Uji F (Chow Test), dan Uji Hausman, maka dapat disimpulan bahwa model pendekatan yang terbaik dalam penelitian ini adalah pendekatan Fixed Effect Model (FEM).

\section{Uji Asumsi Klasik}

\section{Uji Normalitas}

Uji normalitas digunakan untuk melihat atau mendeteksi data berdistribusi normal atau tidak. Jika probabilitas > 0,05 maka data berdistribusi normal, dan sebaliknya.

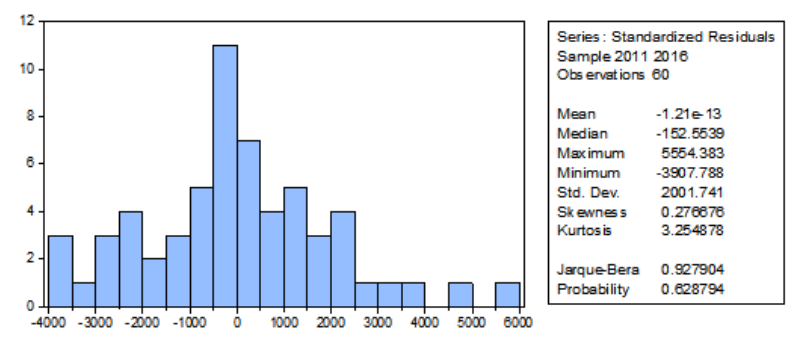

Gambar 1. Hasil uji Normalitas

\section{Uji Multikolinieritas}

Uji multikolinieritas merupakan uji yang dilakukan untuk melihat adanya hubungan atau korelasi antar variabel Independen. variabel independen ada korelasi yang cukup tinggi apabila menunjukkan angka diatas 0,75. 
Tabel 4.

Hasil Uji Multikolinieritas

\begin{tabular}{ccccc}
\hline & ROA & EPS & DER & PBV \\
\hline ROA & 1.000000 & & \\
EPS & 0.213791 & 1.000000 & \\
DER & 0.645323 & -0.072328 & 1.000000 & \\
\hline
\end{tabular}

Sumber: Hasil Uji Multikolinieritas Eviews 8.0, diolah

Sumber: Hasil oleh evies 8.0

Uji tersebut memperlihatkan bahwa keseluruhan hasil dari koefisien korelasi antara masing - masing variabel diatas kurang dari 0,75. Maka kesimpulannya semua variabel yang digunakan dalam penelitian ini bebas multikolinieritas.

3. Uji Heteroskadesitas

Uji ini dilakukan dengan tujuan untuk melihat apakah model tersebut memiliki varian yang sama (homokedastisitas). jika nilai dari hasil dari obs*R-Square Pob.ChiSquare < a (1 persen, 5 persen, 10 persen) maka $\mathrm{HO}$ ditolak dan $\mathrm{Hl}$ diterima.

Tabel 5.

Hasil Uji Heteroskedastisitas

\begin{tabular}{llll}
\hline Heteroskedasticity Test: White & & \\
\hline \hline F-statistic & 2.069871 & Prob. F(3,56) & 0.1145 \\
Obs*R-squared & 5.989054 & Prob. Chi-Square(3) & 0.1121 \\
Scaled explained SS & 9.459585 & Prob. Chi-Square(3) & 0.0238 \\
\hline \hline
\end{tabular}

Hasil tersebut menunjukkan bahwa obs*R-Square Pob.Chi-Square $=0,01121>a$ $(0,05)$, yang artinya bahwa HO diterima dan $\mathrm{H} 1$ ditolak. Sehingga model pada penelitian ini bebas dari heteroskedastisitas.

\section{Hasil Uji Hipotesis}

Model estimasi yang dipilih adalah Fixed Effect Model (FEM). Berikut adalah hasilnya:
Tabel 6.

Hasil F Fixed Effect Model (FEM).

DependentVariable: HARGA_SAHAM

Method: Panel Least Squares

Date: 07/30/18 Time: $13: 27$

Sample: 20112016

Periods included: 6

Cross-sections included: 10

Total panel (balanced) observations: 60

\begin{tabular}{|c|c|c|c|c|}
\hline Variable & Coefficient & Std. Error & t-Statistic & Prob. \\
\hline c & 7.357887 & 0.745749 & 9.866437 & 0.0000 \\
\hline ROA & 0.090036 & 0.120769 & 0.745522 & 0.4597 \\
\hline EPS & 0.129395 & 0.139642 & 0.926620 & 0.3589 \\
\hline DER & 0.133823 & 0.094720 & 1.412829 & 0.1643 \\
\hline \multicolumn{5}{|c|}{ Effects Specification } \\
\hline \multicolumn{5}{|c|}{ Cross-section fixed (dummy variables) } \\
\hline R-squared & 0.972954 & \multicolumn{2}{|c|}{ Mean dependent var } & 8.749780 \\
\hline Adjusted R-squared & 0.966048 & \multicolumn{2}{|c|}{ S.D. dependent var } & 1.284673 \\
\hline S.E. of regression & 0.236715 & \multicolumn{2}{|c|}{ Aksike info criterion } & 0.145213 \\
\hline Sum squared resid & 2.633588 & \multicolumn{2}{|c|}{ Schwarz criterion } & 0.598988 \\
\hline Log likelihood & 8.643611 & \multirow{2}{*}{\multicolumn{2}{|c|}{$\begin{array}{l}\text { Hannan-Quinn criter. } \\
\text { Durbin-Watson stat }\end{array}$}} & 0.322709 \\
\hline F-statistic & 140.8959 & & & 1.452011 \\
\hline Prob(F-statistic) & 0.000000 & & & \\
\hline
\end{tabular}

Berdasarkan hasil pengujian analisis regresi data panel pada tabel diatas, maka dapat disusun persamaan model regresi sebagai berikut:

Harga saham $=-2524.853+12,01146$ ROA + 11.92937 EPS + 149,9124 DER

+ error

\section{Uji $R^{2}$ / Koefisien Determinasi}

Koefisien determinasi ini akan menunjukan kemampuan dari variabel independen secara bersama - sama dalam mempengaruhi disetiap perubahan yang terjadi pada variabel dependen. Kriteria dari uji ini yaitu semakin mendekati angka 1, maka semakin kuat variabel independen dalam menerangkan variabel dependennya.

Berdasarkan hasil dari olah data yang telah dilakukan, diperoleh angka $R^{2}$ yaitu sebesar 0,962422. Artinya sebesar 96,24\% perubahan harga saham dipengaruhi oleh variabel independen yang terdiri dari Return On Asset (ROA), Earning Per Share (EPS), dan Debt To Equity Ratio (DER), sedangkan sisanya sebesar $3.76 \%$ dijelaskan oleh variabe lainnya diluar penelitian ini. 
Ningtias, et al/Jurnal Ekonomi Syariah Teori dan Terapan Vol. 6 No. 1 Januari 2019: 70-81; PENGARUH FAKTOR FUNDAMENTAL TERHADAP HARGA SAHAM SYARIAH PADA PERUSAHAAN YANG TERDAFTAR DI JAKARTA ISLAMIC INDEK PERIODE 2011-2016

\section{Uji $\dagger$ (Parsial)}

Uji parsial (Uji †) digunakan untuk menguji dan membuktikan apakah masingmasing variabel independen secara individu mempengaruhi variabel dependen. Hipotesis dari pengujian ini yaitu:

$\mathrm{H}_{0}:$ Variabel independen secara parsial tidak signifikan berpengaruh tehadap variabel dependen.

$\mathrm{H}_{1}$ : Variabel independen secara parsial berpengaruh signifikan tehadap variabel dependen.

Kriteria dalam penerimaan $\mathrm{HO}$ dan $\mathrm{H} \mathrm{l}$ adalah dengan melihat nilai probabilitas ( $p$ value) dari masing-masing variabel. Jika nilai probabilitas lebih kecil dari 0,05 (taraf kepercayaan 95\%) maka $\mathrm{HO}$ ditolak dan $\mathrm{HI}$ diterima Begitu juga sebaliknya. Berikut adalah hasil uji t:

1. Return on asset menunjukkan angka $0.8973>$ a $(0,05)$. Dari hasil analissi tersebut, maka kesimpulan yang dapat diambil dari adalah menerima $\mathrm{H}_{0}$ dan menolak $\mathrm{H}_{1}$ yang berarti return on asset (ROA) berpengaruh tidak signifikan terhadap harga saham perusahaan.

2. Earning per share ratio menunjukkan angka $0,0000<a(0,05)$. Dari analisis model yang terpilih, maka dapat diambil kesimpulan bahwa $\mathrm{H}_{0}$ ditolak dan menerima $H_{1}$ yang berarti earning per share berpengaruh signifikan terhadap harga saham perusahaan.

3. Debt to equity ratio menunjukkan angka $0.0000<a(0,05)$. Hasil analisis tersebut dapat diambil kesimpulan bahwa Ho ditolak dan menerima $\mathrm{H}_{1}$. Hal tersebut berarti debt to equity ratio berpengaruh signifikan terhadap harga saham perusahaan.

\section{Uji F (Simulan)}

Uji F (Uji Simultan) dilakukan untuk mengetahui apakah variabel - variabel independen secara bersama - sama dapat mempengaruhi perubahan harga saham perusahaan. Hasil dari perhitungan uji $F$ seperti yang ditunjukkan pada tabel 4.7 diatas menunjukkan bahwa probabilitas $\mathrm{F}=$ $0,000000<a(0,05)$. Hasil dari pengujian ini menunjukkan bahwa variabel Return on asset, Earning per share, Debt to equity ratio. secara signifikan berpengaruh terhadap harga saham syariah. Dengan demikian hipotesis dalam penelitian ini terbukti karena $\mathrm{H}_{1}$ diterima dan $\mathrm{H}_{0}$ ditolak.

\section{PEMBAHASAN}

\section{Pengaruh secara Parsial Return On Asset}

\section{(ROA) terhadap Harga Saham}

Berdasarkan dari hasil analisis model yang terpilih pada Tabel 4.7 menunjukkan hasil uji parsial return on asset berpengaruh tidak signifikan dengan arah positif terhadap harga saham syariah. . Hal tersebut ditunjukkan dengan koefisien positif sebesar 12.01146 dan nilai probabilitasya sebesar 0.8973 lebih besar dari tingkat signifikan $5 \%(a=0,05)$.

Hasil dari penelitian ini tidak sesuai dengan penelitian yang dilakukan oleh Cahyaningrum \& Antikasari (2017) yang menyatakan bahwa return on asset berpengaruh signifikan dan mempunyai 
arah positif terhadap harga saham. Sebaliknya, hasil pengujian ini sesuai dengan penelitian yang dilakukan oleh Sugianto (2014) yang menyatakan bahwa return on asset tidak mempunyai pengaruh yang signifikan terhadap harga saham.

Penggunaan aktiva perusahaan akan berpengaruh kepada kegiatan operasional perusahaan dalam proses transaksi penjualan, sehingga hal tersebut akan berpengaruh terhadap perolehan laba. Kondisi tersebut menunjukkan bahwa investor lebih mementingkan hal lain dari pada laba bersih dan tingkat penjualan yang diperoleh perusahaan, misalnya faktor keamanan dalam berinvestasi.

\section{Pengaruh secara Parsial Earning Per Share} (EPS) terhadap Harga Saham Syariah

Berdasarkan dari hasil analisis model yang terpilih pada Tabel 4.7, menunjukkan hasil uji parsial earning per share berpengaruh secara signifikan dengan arah positif terhadap harga saham syariah. Hal tersebut ditunjukkan dengan koefisien positif sebesar 11.92937 dan nilai probabilitasnya sebesar 0.0000 lebih kecil dari tingkat signifikansi $5 \%(a=0,05)$. Koefisien yang menunjukkan angka positif ini memiliki arti bahwa semakin tinggi nilai earning per share maka semakin tinggi pula harga saham perusahaan, begitupun sebaliknya.

Hasil tersebut juga sama dengan hasil yang dilakukan oleh Cahyaningrun dan Antikasari (2017) menunjukkan bahwa earning per share berpengaruh signifikan dan mempunyai arah positif terhadap harga saham. Hasil dari penelitian yang menunjukkan earning per share berpengaruh positif dan signifikan terhadap harga saham sesuai dengan teori signal. Semakin tinggi nilai earning per share berarti semakin baik kinerja dari perusahaan tersebut, sehingga saham yang dimiliki perusahaan akan banyak diminati oleh investor. Dengan demikian, perusahaan akan selalu meningkatkan nilai earning per share untuk menarik minat investor untuk memeli saham tersebut sehingga harga saham perusahaan akan terus meningkat.

\section{Pengaruh secara Parsial Debt To Equity Ratio} (DER)) terhadap Harga Saham Syariah

Berdasarkan dari hasil analisis model yang terpilih pada Tabel 4.7, menunjukkan hasil uji parsial debt to equity rasio berpengaruh secara signifikan dengan arah positif terhadap harga saham syariah. Hal tersebut ditunjukkan dengan koefisien positif sebesar 149.9124 dan nilai probabilitasnya sebesar 0.0000 lebih besar dari tingkat signifikansi $5 \%(a=0,05)$.

Hasil penelitian ini sesuai dengan penelitian yang dilakukan oleh Perdana dkk (2013). Penelitian tersebut menunjukkan bahwa terdapat pengaruh yang signifikan terhadap harga saham dengan arah positif. Dalam kinerja keuangan debt to equity rasio menunjukkan kemampuan perusahaan dalam mengelolah ekuitas untuk menangani dan memenuhi kewajiban jangka panjang atau hutang jangka panjang.

Dalam kinerja keuangan debt to equity rasio menunjukkan kemampuan perusahaan dalam mengelolah ekuitas untuk menangani dan memenuhi kewajiban jangka panjang atau hutang jangka 
Ningtias, et al/Jurnal Ekonomi Syariah Teori dan Terapan Vol. 6 No. 1 Januari 2019: 70-81; PENGARUH FAKTOR FUNDAMENTAL TERHADAP HARGA SAHAM SYARIAH PADA PERUSAHAAN YANG TERDAFTAR DI JAKARTA ISLAMIC INDEK PERIODE 2011-2016

panjang. Perusahaan yang besar cenderung memiliki hutang dengan jumlah yang banyak untuk dijadikan sebagai modal dalam mengeloloah dan mengembangan perusahaan tersebut sehingga perusahaan dapat mengelolah kegiatan operasionalnya dengan baik dalam memperoleh keuntungan.

Pengaruh secara Simultan Return On Asset (ROA), Earning Per Share (EPS), Debt To Equity Ratio (DER) dan Price Book Value (PBV) terhadap Harga Saham Syariah

Berdasarkan dari hasil analisis model yang terpilih pada Tabel 4.7, menunjukkan hasil uji simultan nilai probabilias F-statistik sebesar 0,0000000 nilai yang lebih kecil dari tingkat signifikansi 5\% $(a=0,05)$. Maka dapat disimplkan bahwa variabel independen Return On Asset (ROA), Earning Per Share (EPS), dan Debt To Equity Ratio (DER)) berpengaruh secara signifikan terhadap harga saham syariah. Besarnya pengaruh variabel independen tersebut terhadap harga saham dapat dilihat dari nilai koefisien berganda (adjusted $\mathrm{R}^{2}$ ) pada tabel 4.7 yaitu sebesar 0.962422 . Hal tersebut memiliki arti bahwa sebesar $96,24 \%$ harga saham perusahaan yang terdapat di Jakarta Is/amic Index dapat dijelaskan oleh ukuran variabel independen tersebut, dan sisanya dijelaskan oleh faktor lain diluar perusahaan.

\section{KESIMPULAN}

Berdasarkan hasil analisis dan pembahasan tentang pengarauh return on asset, earning per share, dan debt to equity ratio terhadap harga saham di Jakarta Islamic Index periode 2011 - 2016 yang terlah diulas pada bab sebelumnya, maka dapat ditarik kesimpulan sebagai berikut:

1. Berdasarkan hasil perhitungan uji parsial atau uji $t$ menunjukan variabel independen return on asset memiliki pengaruh yang positif tidak signifikan terhadap harga saham. Sedangkan variabel earning per share, dan debt to equity ratio memiliki pengaruh yang signifikan pada Perusahaan yang terdaftar di Jakarta Islamic Index tahun 2011 2016.

2. Berdasarkan hasil perhitungan uji simultan atau uji $F$ menunjukkan bahwa variabel independen return on asset, earning per share, dan debt to equity ratio value mempunyai pengaruh yang signifikan terhadap harga saham perusahaan yang terdaftar di Jakarta Islamic Index tahn 2011 2016.

\section{Saran}

Berdasarkan hasil penelitian dan kesimpulan, saran yang dapat diberikan oleh penulis adalah sebagai berikut:

1. Bagi Emiten

Perusahaan - perusahaan atau emiten harus lebih memperhatikan dan meningkatkan faktor fundamental perusahaan. Perusahaan khususny pada pembagian laba terhadap emegang saham.

2. Bagi investor

Bagi investor sebaiknya benar - benar memperhatikan keuangan perusahaan sebelum melakukan investasi. Karena faktor keuangan perusahan terutama rasio 
Ningtias, et al/Jurnal Ekonomi Syariah Teori dan Terapan Vol. 6 No. 1 Januari 2019: 70-81; PENGARUH FAKTOR FUNDAMENTAL TERHADAP HARGA SAHAM SYARIAH PADA PERUSAHAAN YANG TERDAFTAR DI JAKARTA ISLAMIC INDEK PERIODE 2011-2016

keuangan sangat memepengaruhi harga saham dan menunjukkan kinerja perusahaan itu sendiri. Selain itu, investor disarankan melakukan investasi pada perusahaan yang terdaftar di Jakarta Islamic Index karena perusahaan perusahaan tersebut telah sesuai dengan.

3. Bagi penelitian Selanjutnya Penelitian ini dharap dapat menjadi refensi bagi penelitian selanjutnya dengan memperpanjang periode penelitian dan menambah jumlah penelitian serta memungkinkan untuk menggunakan variabel - variabel independen lainnya yang berhubungan dengan harga saham syariah.

\section{DAFTAR PUSTAKA}

Al-Qur'an Al-Kariim. Terjemahan. Departemen Agama Islam

Anshori, Muslich \& Sri Iswati. 2009. Metodologi Penelitian Kuantitatif. Surabaya: Pusat Penerbitan dan Percetakan Unair (AUP)

Cahyaningrum. Yustina Wahyu \& Tiara widya Antikasari. 2017. "Pengaruh Earning Per Share, Price To Book Value, Return On Asset, dan Return On Equity Terhadap Harga Saham Sektor Keuangan". Jurnal Economia, Vol.13, No. 2

Dwi Prastowo dan Rifka Julianti, 2002. Analisis Laporan Kevangan (Konsep dan Aplikasi), Edisi Revisi, Yogyakarta : YPKN.

Fathoni, Erik Mahfud. 2014. Pengaruh Faktor - Faktor Fundamental Terhadap Harga Saham Syariah Sektor Consumer Goods Di Bursa Efek
Indonesia periode 2011-2013. Jakarta: Fakultas Syariah Dan Hukum UIN Syarif Hidayatullah

Jakarta Islamic Index (JII). www.sahamok.com

Kasmir. 2015. Analisis Laporan Keuangan. Jakarta: PT Raja Grafindo Persada.

Muhammad. 2014. Manajemen Keuangan Syariah. Yogyakarta; UPP STIM YKPN.

Novitasari, Puput. 2015. "Pengaruh Current Ratio, Total Asset Turnover, Debt to Equity Ratio, dan Return On Equity Terhadap Harga Saham Pada Perusahaan Yang Terdaftar Di JII Periode 2009 - 2013. Surabaya: Jestt Vol.2 No.4 April 2015

Otoritas Jasa Keuangan : https://ojk.go.id/

Perdana, Rizki Agustin Putri dkk. 2013. Pengaruh Return On Equity (ROE), Earning Per Share (EPS) dan Debt To Equity Ratio (DER) terhadap Harga Saham Syariah (Studi Pada Perusahaan Makanan dan Minuman yang Go Public di Bursa Efek Indonesia Periode 2008-2011). Malang: Jurnal Administrasi Bisnis (JAB) | Vol. 2 No. 1 Mei 2013|

Safitri, Abied Luthfi. 2013. Pengaruh Earning Per Share, Price Earning Ratio, Return On Asset, Debt To Equity Ratio dan Market Value Added terhadap Harga Saham dalam Kelompok Jakarta Islamic Index. Semarang: Universitas Negeri Semarang

Samsul, Muhamad. 2006. Pasar Modal Dan Manajemen Portofolio. Surabaya: Penerbit Erlangga. 
Ningtias, et al/Jurnal Ekonomi Syariah Teori dan Terapan Vol. 6 No. 1 Januari 2019: 70-81; PENGARUH FAKTOR FUNDAMENTAL TERHADAP HARGA SAHAM SYARIAH PADA PERUSAHAAN YANG TERDAFTAR DI JAKARTA ISLAMIC INDEK PERIODE 2011-2016

Tandelin, Eduardus. 2010. Portofolio dan Investasi Teori dan Aplikasi. Yogyakarta: Kanisius (anggota IKAP). Undang-undang Nomor 8 Tahun 1995 tentang Pasar Modal.2010. www.ojk.go.id

Undang-undang Republika Indonesia Nomor 25 Tahun 2007 Tentang pasar Modal. www.bi.go.id

Windarini, Ni Luh Putu. 2013. "Pengaruh Beberapa Faktor Fundamental Kevangan terhadap Harga Saham Pada Perusahaan Consumer Goods Yang Go Public di Pt. Bursa Efek Indonesia"

www.ksei.co.id

Yuliana, Indah. 2010. Investasi Produk Kevangan Syariah. Malang; UIN Maliki Press. 